Canadian Art Review

\title{
“A Residence Fit for Any Gentleman in the Country:” Three Kingston Villas by George Browne
}

\section{Jennifer McKendry}

Volume 19, numéro 1-2, 1992

Art as Propaganda

Art et propagande

URI : https://id.erudit.org/iderudit/1072853ar

DOI : https://doi.org/10.7202/1072853ar

Aller au sommaire du numéro

\section{Éditeur(s)}

UAAC-AAUC (University Art Association of Canada | Association d'art des universités du Canada)

\section{ISSN}

0315-9906 (imprimé)

1918-4778 (numérique)

Découvrir la revue

Citer cet article

McKendry, J. (1992). “A Residence Fit for Any Gentleman in the Country:” Three Kingston Villas by George Browne. RACAR : Revue d'art canadienne / Canadian Art Review, 19(1-2), 68-78. https://doi.org/10.7202/1072853ar

\section{Résumé de l'article}

L’oeuvre de l'architecte George Browne (1811-1885) a été généralement reconnue dans les études architecturales et historiques canadiennes publiées dans Building Canada (1966) d'Alan Gowans, et $A$ Guide to Canadian Architectural Styles (1992), de Leslie Maitland et al. Cependant les textes se référant à l'oeuvre de Browne ne sont basés que sur quelques spécimens de son travail. Le présent article se propose de démontrer et d'illustrer qu'en fait le nombre des résidences conçues par Browne est le double de ce qui lui est généralement concédé pour la période des années 1841 et 1844. Un grand nombre d'historiens lui ont attribué, sans raisons substantielles, Bellevue House, une villa bien connue de style toscan, qu'ils ont aussi datée approximativement. Roselawn, une belle villa de style paladin, attribuée précédemment à un autre architecte de Kingston, lui est ici concédée. Les résidences conçues par Browne durant ces années si importantes pour la ville de Kingston-celle-ci alors la capitale du Haut-Canada et du Bas-Canada-restent des exemples frappants d'une conception de la villa toscane comme demeure populaire où se manifestent un raffinement de son style et de son goût pour le pittoresque.
Tous droits réservés (C) UAAC-AAUC (University Art Association of Canada | Association d'art des universités du Canada), 1994
Ce document est protégé par la loi sur le droit d'auteur. L'utilisation des services d'Érudit (y compris la reproduction) est assujettie à sa politique d'utilisation que vous pouvez consulter en ligne.

https://apropos.erudit.org/fr/usagers/politique-dutilisation/ 


\title{
"A Residence Fit for Any Gentleman in the Country:" Three Kingston Villas by George Browne*
}

\author{
JenNifer MCKENDRY, Kingston, Ontario
}

\section{Résumé}

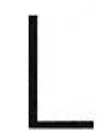

'oeuvre de l'architecte George Browne (1811-1885) a été généralement reconnue dans les études architecturales et historiques canadiennes publiées dans Building Conodo (1966) d'Alan Gowans, et A Guide to Conadion Architectural Styles (1992), de Leslie Maitland et al. Cependant les textes se référant à l'oeuvre de Browne ne sont basés que sur quelques spécimens de son travail. Le présent article se propose de démontrer et d'illustrer qu'en fait le nombre des résidences conçues par Browne est le double de ce qui lui est généralement concédé pour la période des années 1841 et 1844. Un grand nombre d'historiens lui ont attribué, sans raisons subs- tantielles, Bellevue House, une villa bien connue de style toscan, qu'ils ont aussi datée approximativement. Roselawn, une belle villa de style paladin, attribuée précédemment à un autre architecte de Kingston, lui est ici concédée. Les résidences conçues par Browne durant ces années si importantes pour la ville de Kingston - celle-ci alors la capitale du Haut-Canada et du Bas-Canada-restent des exemples frappants d'une conception de la villa toscane comme demeure populaire où se manifestent un raffinement de son style et de son goût pour le pittoresque.
Roselawn, the homestead of Henry Smith, Junr., Esq., Solicitor General, is a large heavy stone building surrounded with fine grounds, and forming a residence fit for any gentleman in the country, and with the tame deer sporting through the rich lawn, forms a picture far too seldom seen in Canada.

$$
\begin{array}{r}
\text { Thomas Flynn, Directory of the City } \\
\text { of Kingston for 1857-1858 }
\end{array}
$$

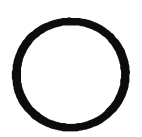
nly three examples of domestic work by George Browne (1811-1885), an Irish immigrant architect, are widely accepted and fully discussed from his years in Kingston, 1841 to 1844: Rockwood Villa (Figs. 1 and 2), St. Andrew's Manse (Fig. 3) and Hales's cottages - all based securely on tender calls from the same year, $1841 . .^{1}$ To this list we can now add three significant examples of picturesque design: Hawthorne Cottage (1841, Fig. 4), Roselawn (1842, Figs. 5 and 6), and Bellevue House (1843, Fig. 9).

Little is known about Browne's training in Ireland, although it is likely that he apprenticed with his architect father and benefited from practical experience as a building superintendent. In 1830 he moved to Québec and ten years later to Montréal. ${ }^{2}$ Among the few buildings definitely assigned to him from this period is the Gothic Revival villa, Benmore (2071 du Chemin St Louis, Sillery) of $1834 .{ }^{3}$ His career gained momentum as Government Architect, and he moved to Kingston when it became the capital of Canada East and Canada West from 1841 to 1844 . His brief stay in Kingston resulted in the design of the City Hall and Market, outstanding examples of Tuscan classicism in textured local limestone, as well as some interesting commercial and residential buildings. He returned in 1844 to Montréal, where his Molson's Bank, now the Bank of Mon- treal, of 1864-66 still stands at Rue St.-Jacques and Rue St.-Pierre.

At least one of these Kingston residences must be reclaimed from an attribution to another architect. An attractive suburban villa, Roselawn (Union Street at College, now part of the Donald Gordon Conference Centre, Queen's University, Kingston, Figs. 5 and 6), has been given in publications to William Coverdale (1801-1865), a successful local architect who designed many handsome villas including Rosemount (46 Sydenham Street at Earl, 1850, Fig. 7) - a direct heir of Bellevue House as a Tuscan villa type. ${ }^{4}$ Roselawn has been assigned by various historians to Coverdale because his accounts and notes (in a private collection) mention David John Smith, lawyer and secondgeneration Loyalist, who bought Roselawn's site (fronting newly created Union Street) in $1841 . .^{5}$ We must, therefore, closely analyse such entries as: payment for Smith's plans and specifications on 10 January 1843, payment for a valuation of Pidgeon's work on "Mr. Smith's Building" in March 1843 , and undated notes on the work necessary for "Mr. D.J. Smith House." Given the proximity of these entries to the date Smith purchased Roselawn's site, it has been assumed that they relate to the villa, but what has been ignored is that the detailed notes describe work involved in repairing or altering an existing building - probably the "large and commodious private dwelling house in Front [now Ontario] Street" that Smith was hoping to improve extensively as a rental property. Examples of Coverdale's alterations include measuring cracked old plaster, taking down an old partition, eight days to take off the old roof, and patching the roof. Coursed and rubble work are mentioned yet Roselawn is only coursed. Smith's notice about the Ontario Street house (the Smith family had owned property at the corner of Ontario and Queen Streets since late 
Figure 1. George Browne, Rockwood Villa, Kingston, 184I, south view (Photo: J. Mckendry).

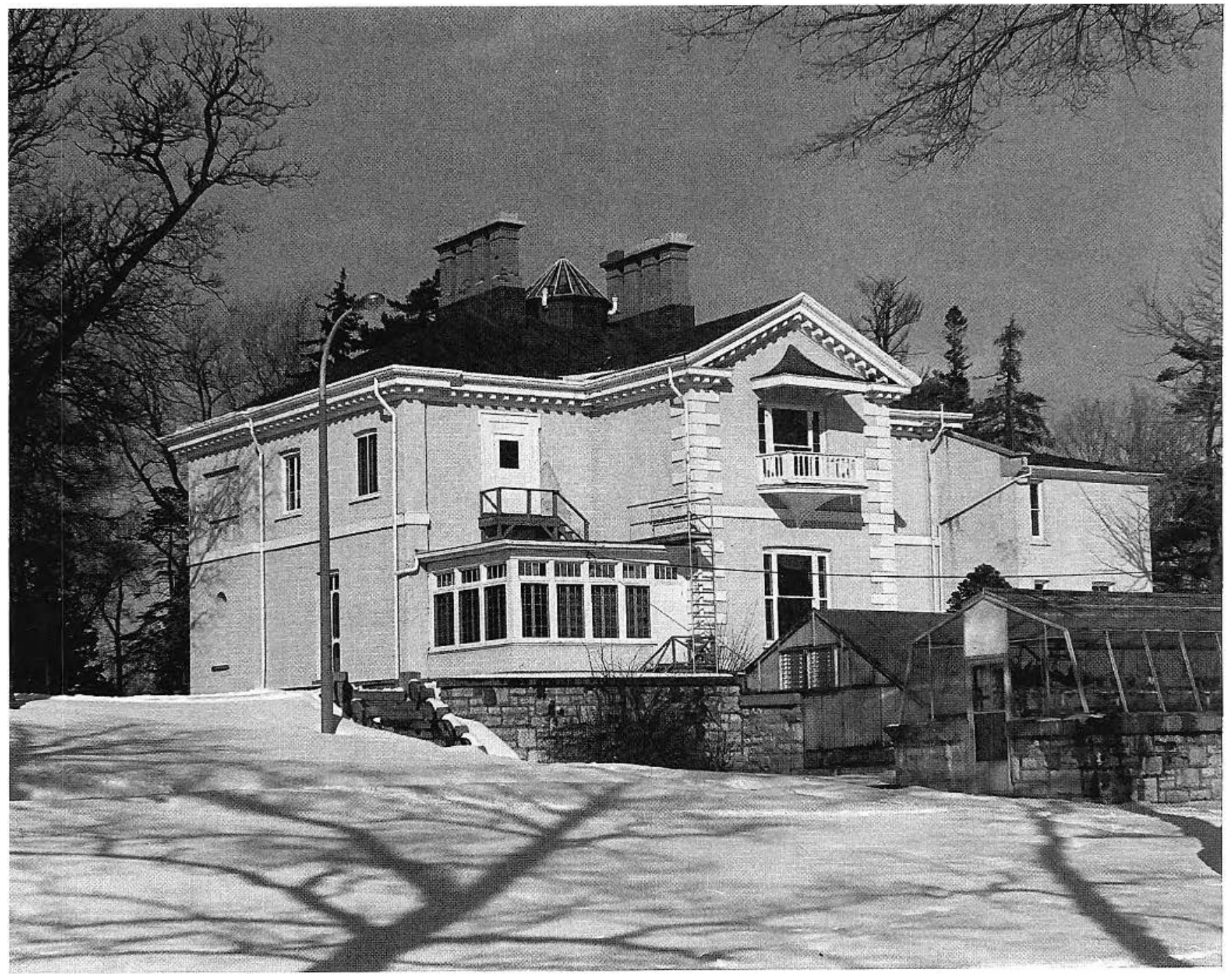

Figure 2. George Browne, Rockwood Stable (demolished), Kingston, 184I (drawing by J. Mckendry).

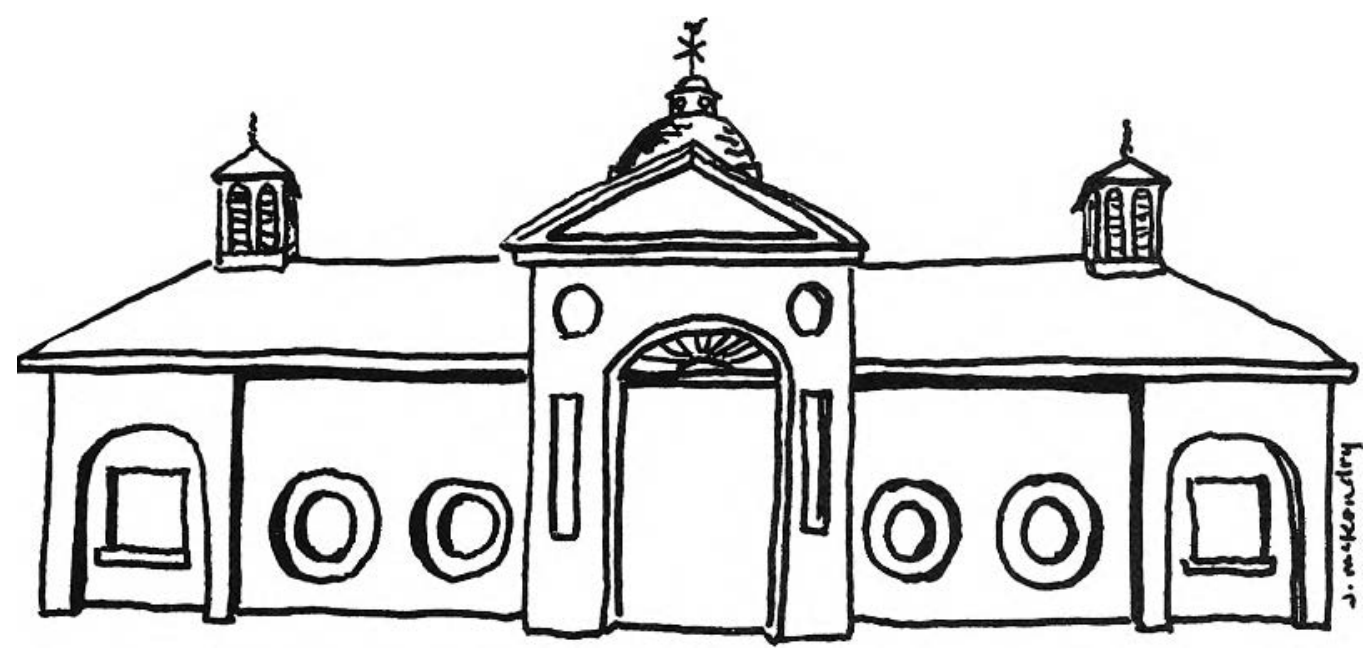


Figure 3. George Browne, St Andrew's Manse, Kingston, 184I (Photo: J. McKendry).

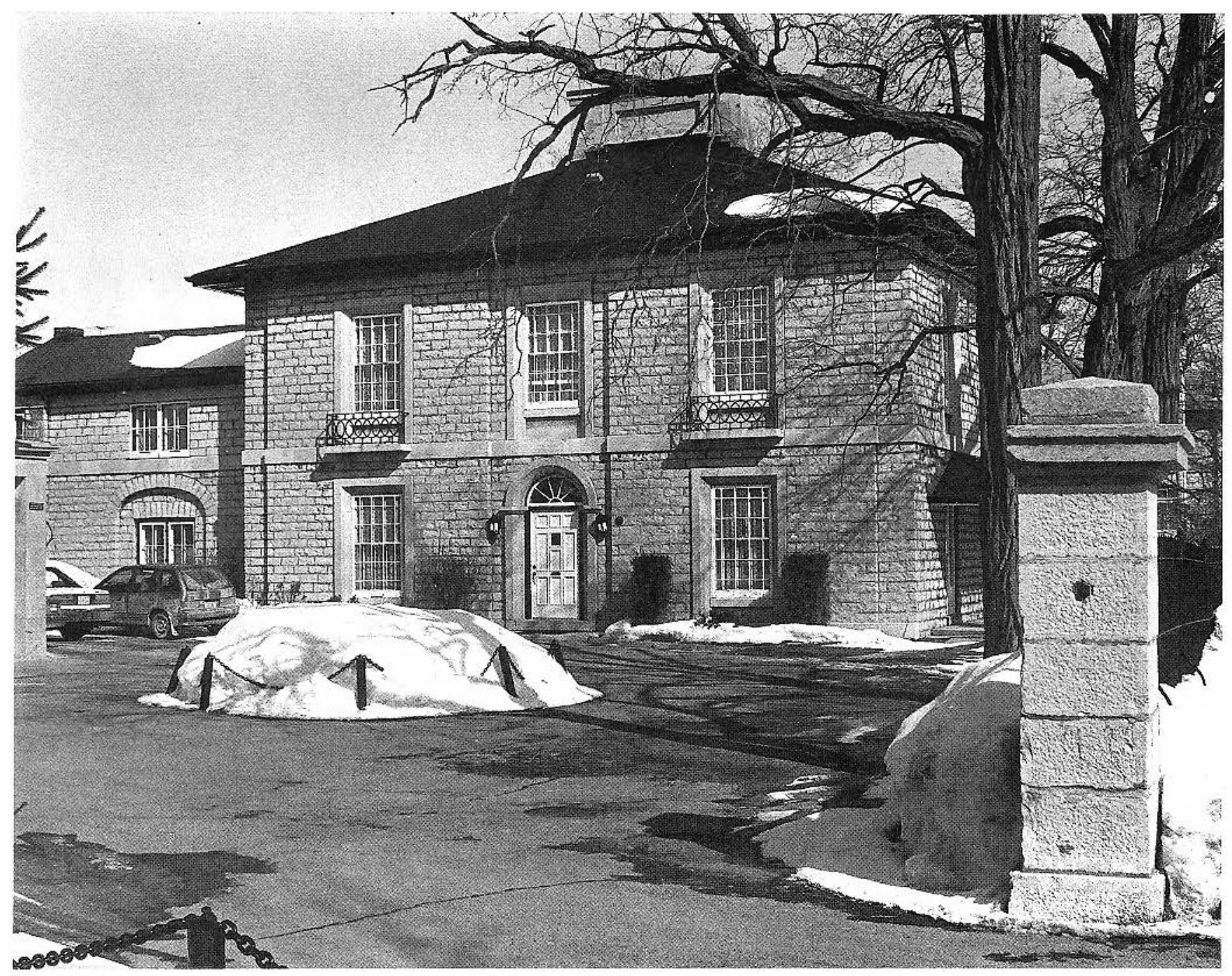

in the eighteenth century) appeared in the Chronicle of Gazette, Kingston, 18 March 1842. City assessments for 1843 (reflecting the previous year) tax Smith for a house at $£ 100$, while in 1844 (reflecting changes in 1843) he is taxed for two buildings, one at $£ 80$, the other "untenanted" at $£ 45$. It is likely that this double house is the result of Coverdale's alteration and division. In fact, it appears that there is no known documentation to associate Roselawn with a particular architect.

Roselawn bears many similarities to documented examples of George Browne's work. The texture of Roselawn's limestone is carefully controlled for maximum aesthetic appeal in ways that are consistent with Browne's practice. The walls are conscientiously textured; the chimneys feature rusticated panels that contrast with surrounding smooth-dressed stone. Browne also uses textural contrasts effectively on St. Andrew's Manse, where the velvety sur- face of window and doorway surrounds and the belt course is played off against the coarse walls (Fig. 3). At Roselawn the resulting play of light and shade over textured stone is enhanced by projecting and receding wall surfaces, as in Browne's Rockwood Villa (Fig. 1) and St. Andrew's Manse.

Browne's houses are generically similar in massing, proportion and roof and chimney form but idiosyncratic aspects are even more convincing indicators of authorship. Roselawn sprouts an unusual masonry garden-wall that acted at one time as a shelter as one walked from the side door of the house to the porte-cochere (Fig. 6). The face of this long blank wall is divided by broad pilaster strips, and the resulting panels contain large and small recesses. In addition there is a niche half-way along the wall. Browne used these relieving devices on Rockwood, the Manse and his preliminary design for Kingston City Hall. The abstract shapes that form the classical design of the Roselawn porte- 
Figure 4. George Browne, Hawthorne Cottage, Kingston, 184I, painting of 1908 (Photo: J. McKendry, courtesy Sisters of Providence of St. Vincent de Paul, Kingston).

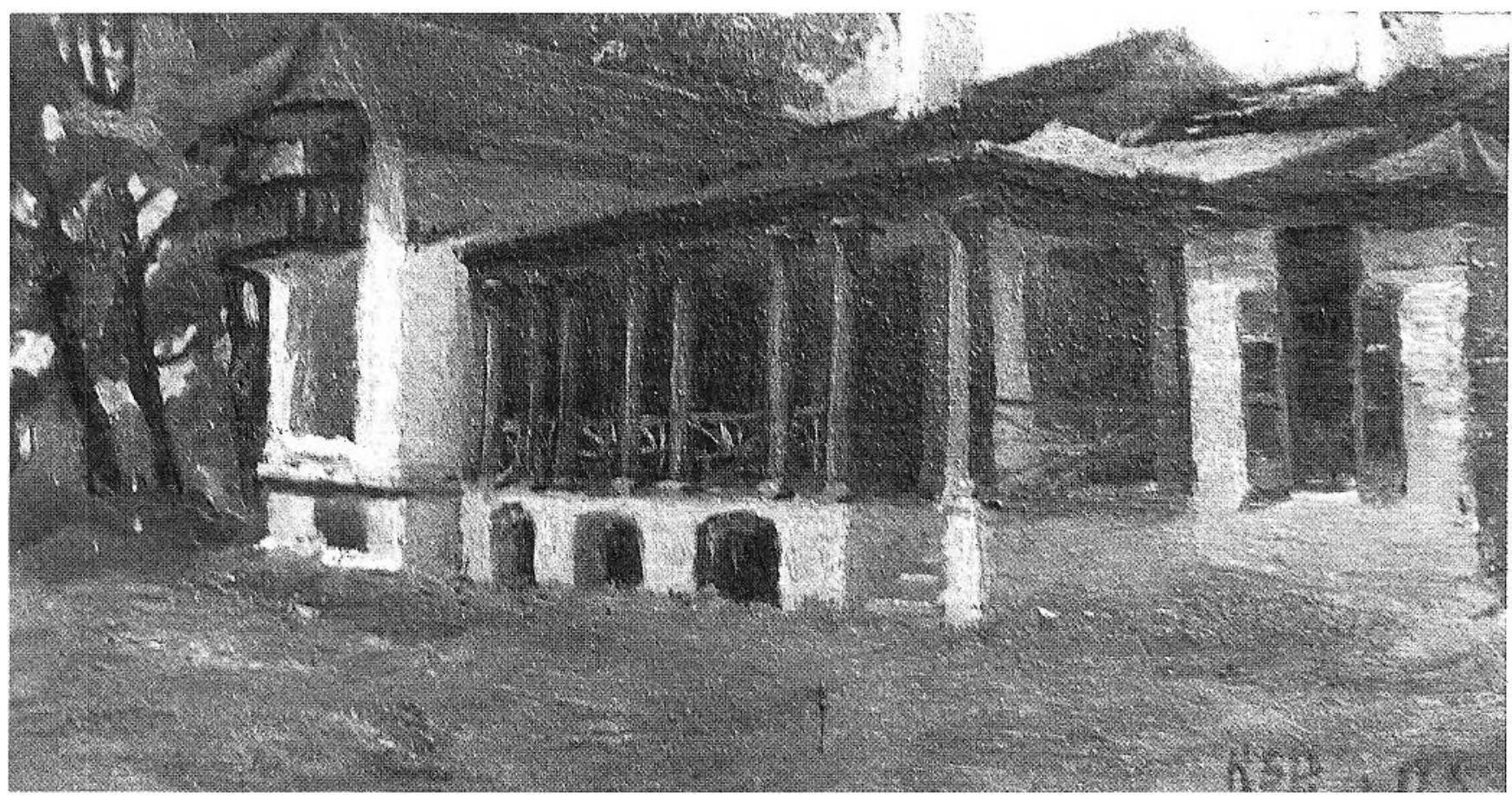

cochere bear a striking resemblance to those on the west face of the Rockwood stables (Fig. 2, demolished) - a design probably derived from Robert Morris's Rural Architecture (1750). ${ }^{6}$

Another individualized feature is the tent canopy and balcony of Roselawn. Browne used this same combination at Rockwood, Hawthorne Cottage, Bellevue and Spencer Wood in Québec, which he went on to design in 1852 (compare Figs. 1, 4, 8, and 9). Walling's 1860 vignette of Roselawn shows the gable window sheltered by a striped and scalloped tent canopy (now missing) supported by trellis-work frames (also missing) that rest on a balustraded balcony, which forms the roof of the porrico (Fig. 5). There is an elegant counterplay between the curves of the awning and the angled lines of the dentilled gable. The gable ends recurn briefly at the level of the canopy fringe, as on the south face of Rockwood (Fig. 1). ${ }^{7}$ And when, in 1852, Browne was called upon to redecorate Spencer Wood (a villa of the late eighteenth century with a gable frontispiece) he applied a heavy version of Roselawn's canopy, balcony and portico (Fig. 8).

Rockwood's master bedroom window faces south towards Lake Ontario. From its canopied balcony lawyer John Cartwright and his wife Sarah enjoyed viewing their landscaped pleasure grounds and the lake (since 1859 the massive stone face of Rockwood Lunatic Asylum has dominated this view) ${ }^{8}$ This window, located above the dining-room window, is bracketed like an upside-down version of an awning, in a manner similar to Hawthorne Cottage, which George Browne enlarged a few months before his designs for Rockwood (Fig. 4).?

The original core of Hawthorne Cottage, F.A. Harper's "clegant cottage on the Penitentiary Road," today's King Street West, dates from $1836 .{ }^{10}$ It was advertised for sale in 1841 as a

Desirable Property ... distant from Town about one mile, consisting of from eight to nine acres of land, on which is erected a nearly ncw stone cottagc, forty feet square, containing dining and drawing rooms and threc bedrooms, on one floor - in the basement are a large kitchen, two rooms for servants, cellars and pantries. A garden house is attached to the west side. Therc are coach house stabling for three horscs, gardener's house, and a large new shed in the rear, as wcll as a well of excellent water. The lawn in front is planted with trees, shrubs, etc., and the road to the house fenced with a quick-set hedge.

In the rear is a large newly fenced garden, well stocked with vines, fruit trecs, asparagus and sea kale beds, etc., sheltered from the north winds by a fine grove of pine trees, through which there is a winding walk.

Two acres of cultivated ground adjoins the greenhouse, and a field of about three-and-a-half acres, for pasture or hay, bounds it in the rear on Union Road, thercby giving the property two fronts. ${ }^{11}$ 
Figure 5. George Browne, Roselawn, Kingston, 1842, detail from Walling's Frontenac County map of 1860 (Photo: J. Mckendry).

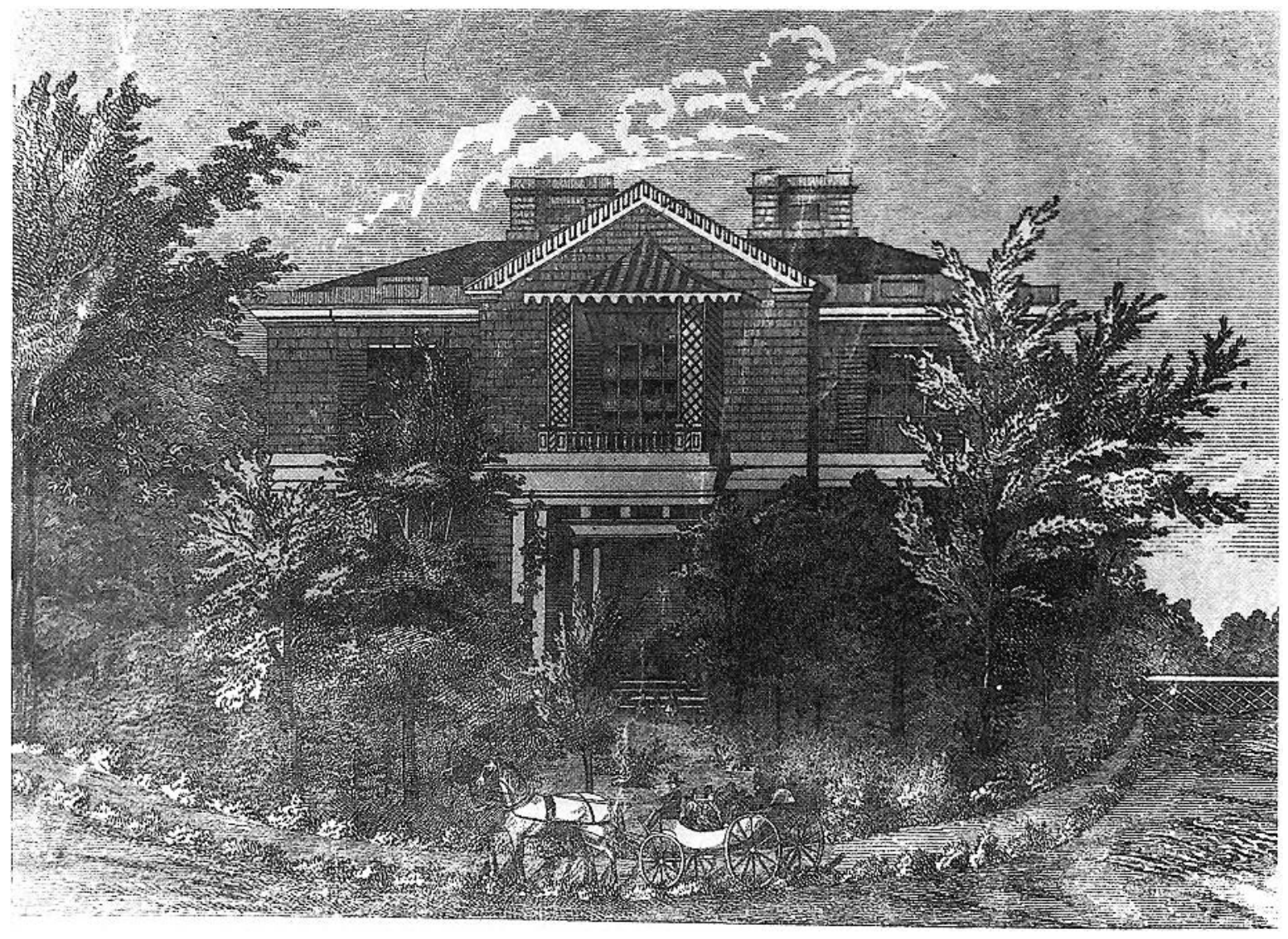

Figure 6. George Browne, Roselawn, Kingston, 1842 (Photo: J. McKendry).

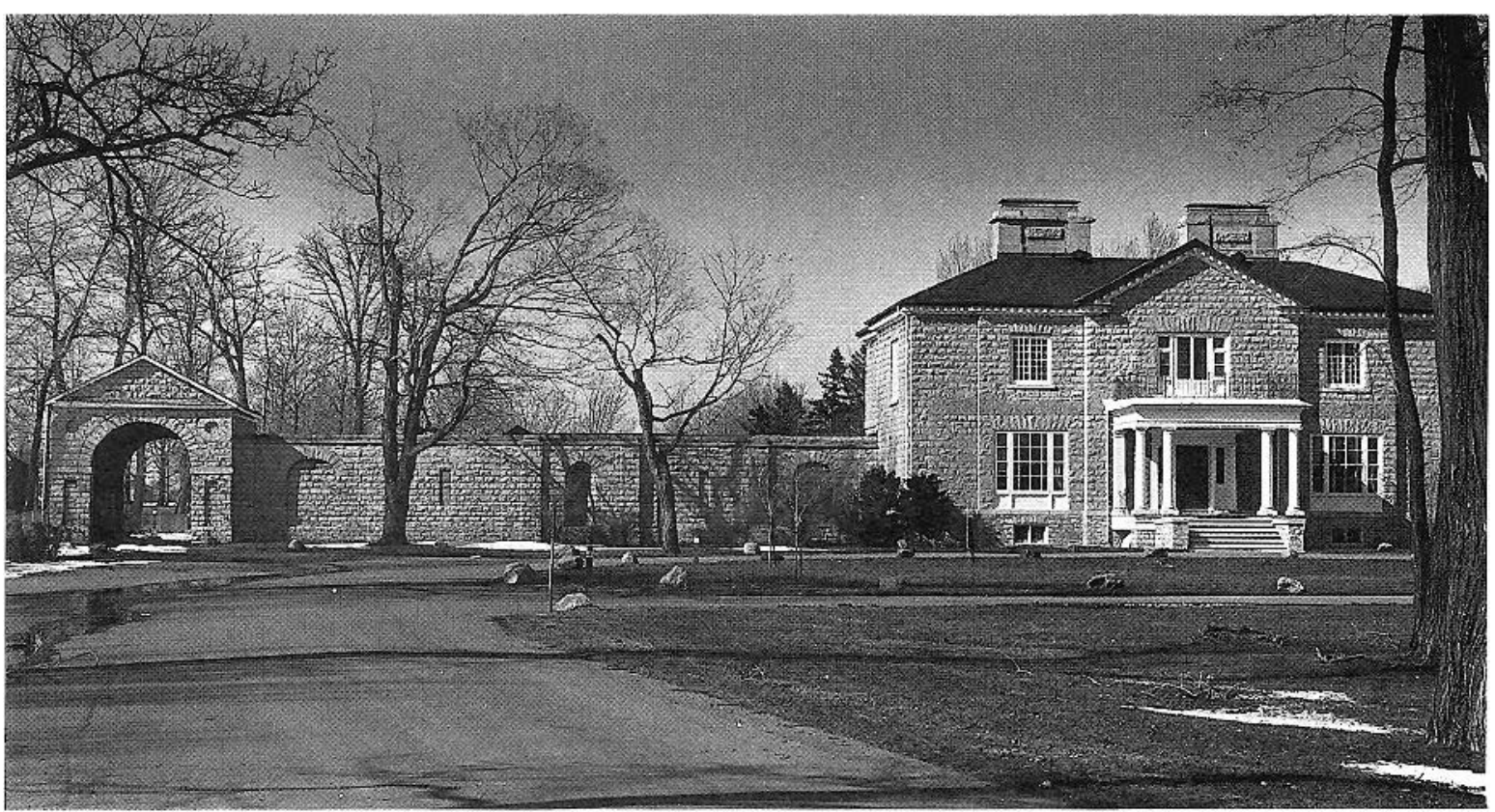


Figure 7. William Coverdale, Rosemount, Kingston, 1850, view in Meacham's county atlas of 1878 (Photo: J. McKendry).

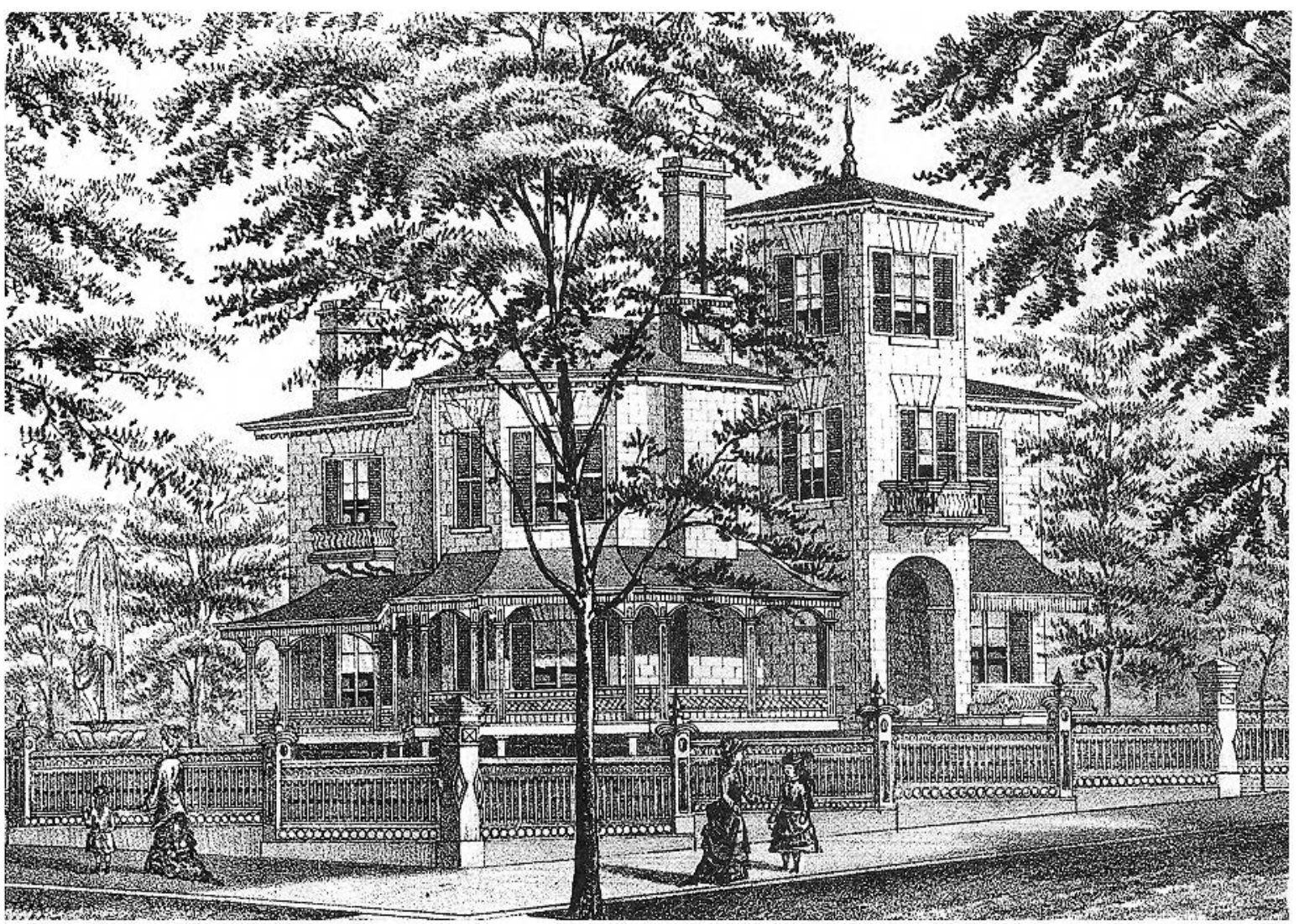

Figure 8. George Browne, proposed alteration of Spencer Wood, Quebec, 1852 (Photo: J. Mckendry, courtesy of National Map Collection, National Archives of Canada, Ottawa).

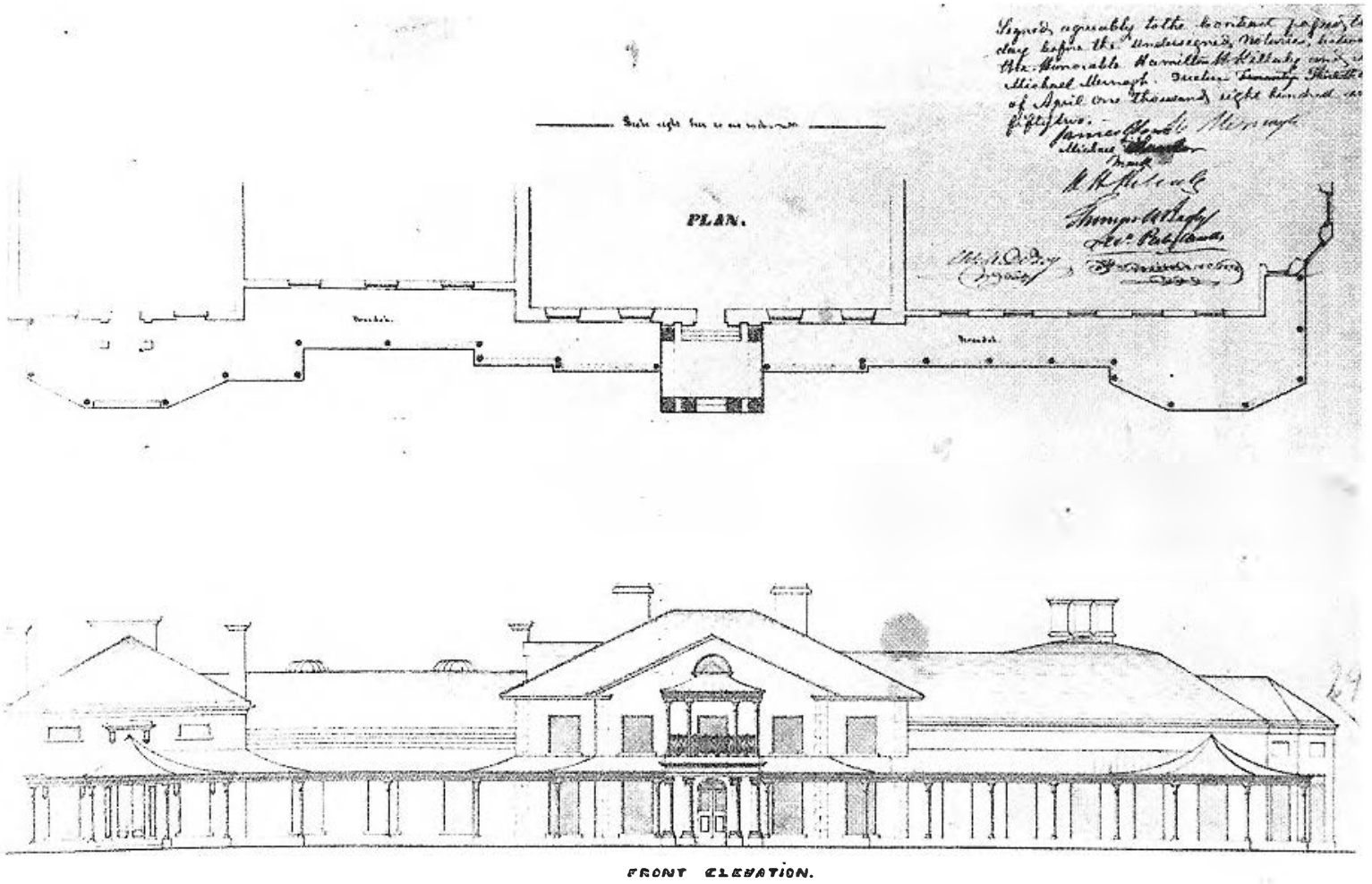


Figure 9. George Browne, Bellevue House, Kingston, 1843 (Photo: J. McKendry).

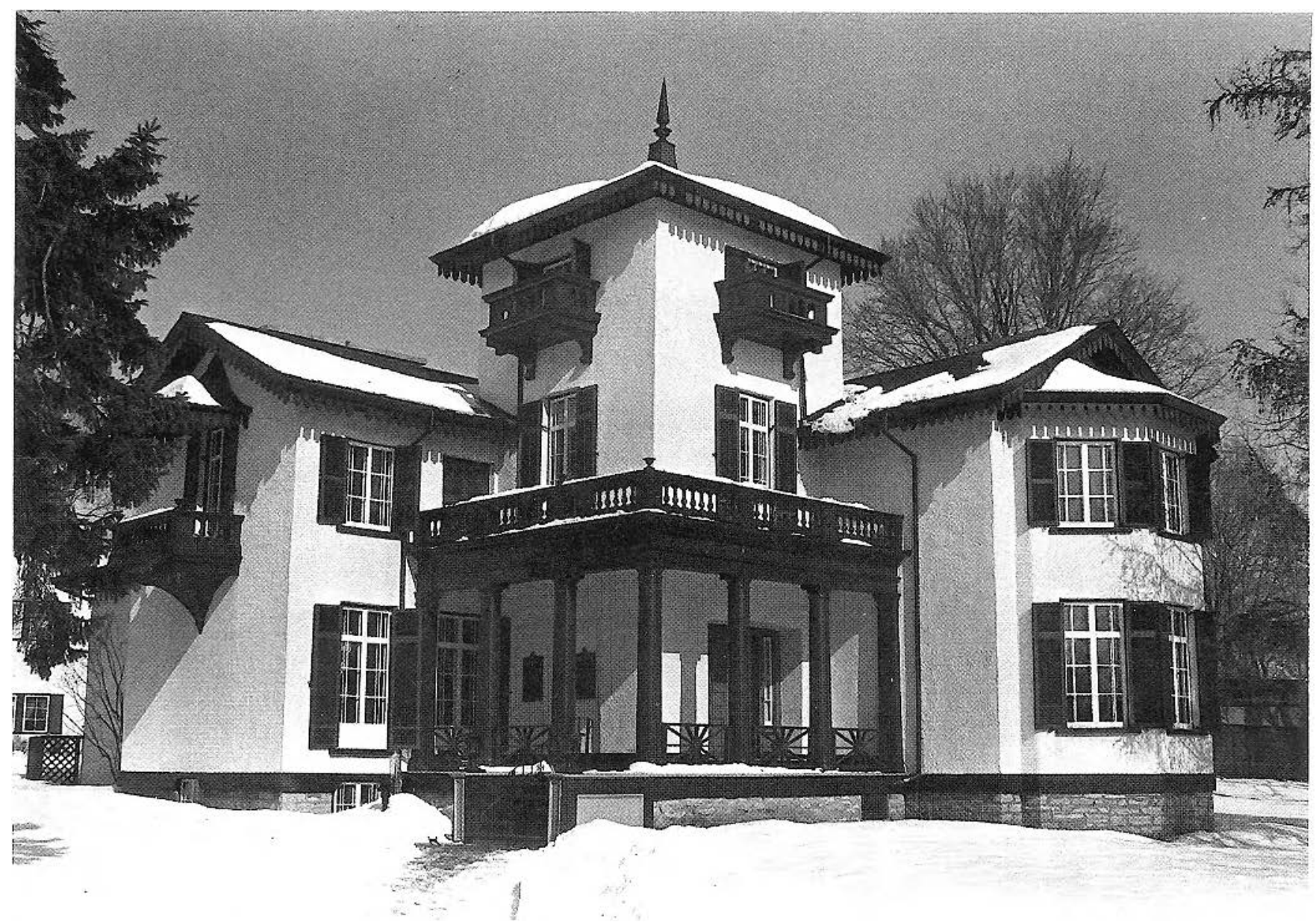

This idyllic sales description paid immediate rewards in the form of a tenant rather than a buyer.

At this moment, when Kingston was transformed into the capital, a high-ranking official, Chief Secretary J.W.C. Murdock, needed a suitable residence, and Hawthorne Cottage was considered "conveniently situated in close vicinity to Alwington House," the Governor General's residence. ${ }^{12}$ Desiring a larger and more elaborate dwelling, Murdock engaged government architect George Browne who had plans "for the wing for servants etc." ready by 19 April 1841. ${ }^{13}$ Browne submitted his expenses in June (amounting to $£ 74.2 .10)$ for work performed "at Chief Secretary's house in building a servants' wing, fitting up pantry, store house and wine cellar and fixing an awning to roof." 14

This and other hints suggest that Browne added the cottage's Tuscan verandah as well as designing the wing with a canopy and balcony - all features of his contemporary domestic work. ${ }^{15}$ Hawthorne Cottage's wing and verandah are in turn clues to discovering the architect of nearby Bellevue House, a national historic site which I attribute to George Browne (Fig. 9).
It is worth establishing the precise building date of Bellevue (35 Centre Street) because 1838, accepted in some secondary sources, would place it among the earliest North American Tuscan villas with towers. ${ }^{16}$ If 1843 is the correct date (as I believe), Bellevue House is among the first of its type in British North America. ${ }^{17}$ Such a date is compatible with my contention that George Browne was the true designer, for he was still in Kingston, and that his design was influenced by an American pattern book of 1842 .

On 11 January 1841, Kingston merchant Charles Hales purchased Bellevue's nine-and-a-half-acre site, bounded on the south by King Street and the lakeshore, and by two newly created streets, Union and Centre, on the north and west. This land was very desirable for development - with three street-frontages, a view of the lake, and proximity to both the town and the Governor General's residence - and consequently was expensive. ${ }^{18}$ Having acquired a mortgage of $£ 1,000$ from Jane McLeod of neighbouring Edgehill, Hales was ready to develop in the spring and authorized George Browne to tender five cottages on the King Street frontage. ${ }^{19}$ 


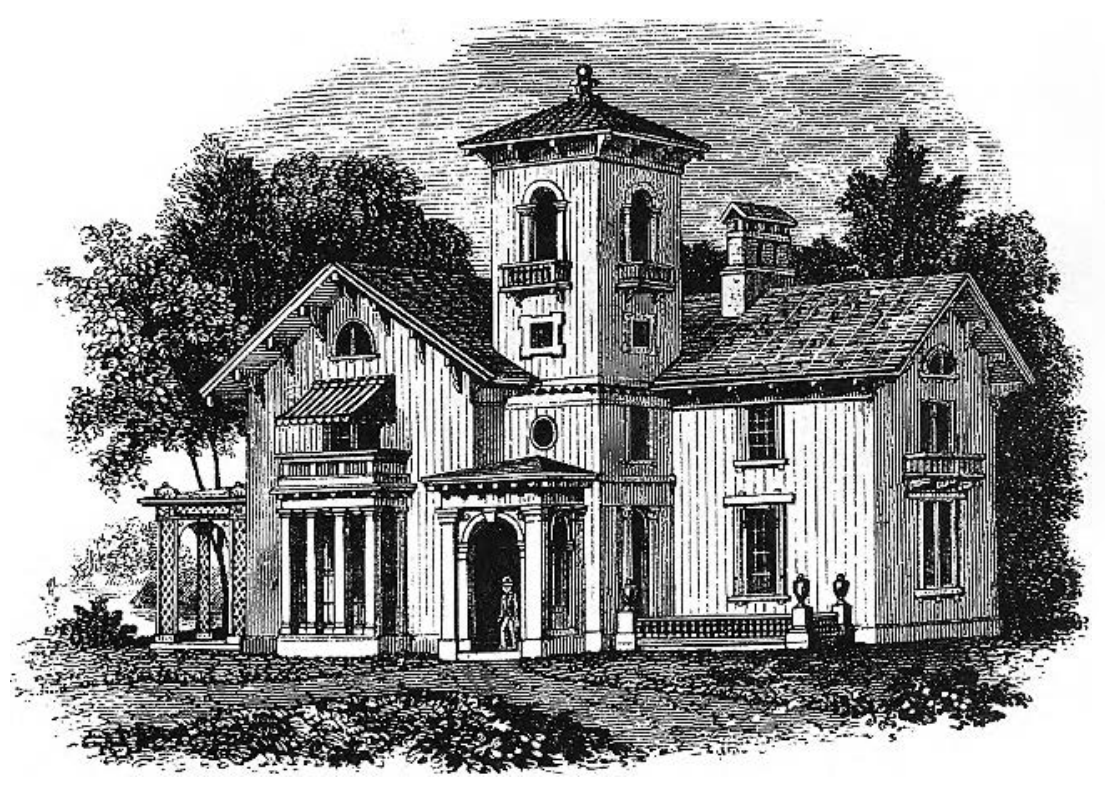

in $1848-49$, their stay marred by the unexpected death of their young son.

In addition to the strong bond of patronage between Charles Hales and George Browne through the cottages and Commercial Mart, Hales sold Browne the William Street lot where the architect built his own house in $1841 .{ }^{24}$ There is a strong affinity between Bellevue and Browne's other houses, including Hales's cottages, in the handling of materials and the treatment of details such as the picturesque fringe at the eaves and the offcentre glazing bars. But whereas the simple regularity of each cottage suits row construction on a confined site, the complex irregularity of the villa is fitting on a more generous and romantic site. The elevated grounds of Bellevue were considered delightful, "commanding a splendid view of the lake, bay, river St. Lawrence, Fort Henry, etc.," according to the Argus, 4 August 1848. The Tuscan verandahs and the two-storey wings of Hawthorne

In the meantime Hales was expanding his business quarters, the Commercial Mart, beside his two town houses at the corner of Ontario and Princess Streets (Fig. 11). George Browne called for tenders on the new section early in 1842 , and this handsome stone building, with a groundstorey arcade complementing the round corner, was ready for occupancy a year later. ${ }^{20}$ We need to weave in the history of this business and residential complex to establish the sequence of dates of Hales's various buildings. By early 1843 Hales, having completed his cottages and the Commercial Mart, was in a position to consider building his villa Bellevue - perhaps as a rental property. ${ }^{21}$ We know that in the spring of 1843 Hales was living in one of his town houses yet was advertising in the British Whig that he wished to lease both of them - perhaps because he was planning to move to his suburban holdings. In the autumn of the next year his life was marred by personal tragedy when his wife and son died. Had Hales waited until 1844, such a project would not have seemed propitious because of the loss of his family and the economic depression following the move of the capital away from Kingston. In the spring of 1845 he was still downtown. ${ }^{22}$ We have no documentation about Bellevue until spring 1846 when "that beautiful villa, belonging to Mr. C. Hales, and presently occupied by Mr. Harvey" was advertised for rent. ${ }^{23}$ The most famous tenants at Bellevue were Isabella and John A. Macdonald
Cottage and Bellevue are especially similar, with a gabled end wall sporting a canopied balcony on a long concave corbel (Figs. 4 and 9).

British and American architectural reference books owned by architects practising in Kingston were helpful tools in designing local buildings. Evidence of Browne's reliance on certain plates from such books - particularly those of Asher Benjamin - can be found in the detailing of Rockwood Villa, Hales's cottages and Roselawn. ${ }^{25}$ When pondering the design of Bellevue House late in 1842 or early in 1843, for instance, Browne probably turned to the illustration of "A Villa in the Italian Style, Bracketed" in Andrew Jackson Downing's Cottage Residences, an American publication available in June 1842 (Fig. 10). Both Downing and Browne created an L-shaped house focused on a square entrance tower or campanile - decorated by balconies and surmounted by a very low-pitched hip roof with deep eaves and a finial - flanked by two-storey, gable-roofed wings.

Such a tall tower, "one bold well placed part" as described by John C. Loudon in his famous Encyclopaedia, acts as a centre for one's field of vision in an irregular pile of buildings. ${ }^{26}$ Samuel Sloan in The Model Architect of 1851-52 says that such towers in modern Italian houses are called campaniles, a term originating in the detached bell towers of medieval Italy. ${ }^{27}$ This term is also used by Downing in Cottage Residences (1842) and The Architecture of Country Houses (1850). 
Figure 11. George Browne, Commercial Mart, Kingston, 1842, detail from Daily British Whig, 6 January 1874 (Photo: J. Mckendry).

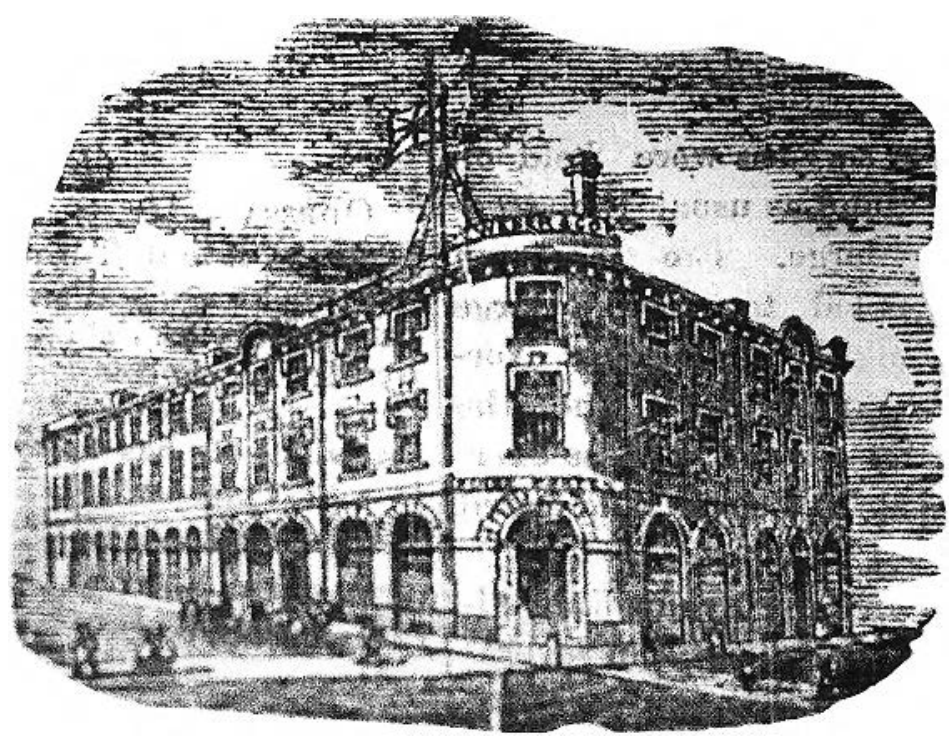

I have taken a cottage or rather, I beg its pardon a Villa near Harper's cottage [Hawthorne Cottage .... It is a large roomy house for a retired grocer, who was resolved to have an "Eyetalian Willar," and has built the most fantastic concern imaginable. From the previous laudable tho' rather prosaic pursuits of the worthy landlord the house is variously known in Kingston as Tea Caddy Castle, Molasses Hall and Muscovado Cottage ... ${ }^{30}$

Bellevue House is a logical development in Browne's domestic work, a fully realized picturesque suburban retreat: it is an Italian villa with tower, varied silhouette and bold detailing all of which respond to the pictorial nature of the site to provide a dwelling suited to the social aspirations of the architect's client.

The Italian villa is a nineteenth-century de-

At Bellevue, Browne improved upon the model offered by Downing (who shows a modest portico stuck insecurely to one side of the tower). Browne convincingly wraps his verandah around both exposed sides of the tower and exploits the verandah roof for a balustraded balcony. He had already experimented with this double function at Rockwood, his earlier Italian villa, in the portico with balcony on each side of the south wing. ${ }^{28}$ Further, Browne's Bellevue has a strong sculptural quality that presents a bold face to the viewer.

Various British writers were describing Tuscan or Italian villas in the early nineteenth century. Peter Frederick Robinson's Designs for Ornamental Villas (4th edn, 1836), for example, includes "A Residence in the Style of Building in Tuscany" described in the following manner:

The campanile is a feature peculiar to this 'Tuscan architecture, and its form establishes local recollections. In the works of the great Italian masters it is frequently introduced .... The design, No. 16, is formed upon an Italian model . . . . The surface upon which the building is proposed to be situated, is much varied, and the pictorial effect consequently produced is favourable to the style of architecture . . . 29

This notion of the individual qualities of topography affecting one's choice of style may have appealed to Browne as an architect and landscape gardener. The site of Hales's proposed villa certainly has a pictorial quality. The idea, however, of Charles Hales as a modern merchant-prince expressing himself pretentiously through this house was gently mocked by his tenant John A. Macdonald: velopment of the eighteenth-century Picturesque movement in Britain. Influential British architect John Nash was involved in designing residences that merged easily into the natural yet controlled landscape schemes of Humphry Repton. This encouraged Nash's interest in the old vernacular architecture of Italy, as portrayed by the Baroque landscape painters Poussin and Claude Lorrain. Nash's Cronkhill, an early nineteenth-century essay in this type of house, features a strong corner tower, broad eaves with brackets and round-arch windows. Classical detailing is offered as an alternative to rambling British castles with Gothic detailing. The freedom to compose blocks of a building in such a way that plans and silhouettes were varied, appealed strongly to Americans, who took up the cause around $1840 .{ }^{31}$

George Browne, a young ambitious architect with a strong interest in landscape design, was quick to appreciate the creative freedom of this style and its adaptability to upper middle-class housing. He demonstrated an interest in British picturesque traditions in his career, and was attracted to the sculptural forms of Sir John Soane's designs. Widely read, Browne no doubt followed these developments in Britain and the United States (where he travelled in 1836). Bellevue House is perhaps the earliest example in Canada of a modestly sized Italian villa with a tower and follows hard on the heels of American examples. It is a striking design: its white rough-cast walls stand out against the green vegetation of summer and its painted wooden trim against the white snows of winter. There may be minor awkward aspects and a reluctance to incorporate round arches, but these are simply signs of experimenting with a novel style. In this Canadian building we have a fine con- 
tribution to the development of asymmetrical and free planning in the designing of residences.

* This article has evolved from the author's work on her forthcoming book, With Our Past Before Us: Architecture of 19th Century Kingston and Area, University of Toronto Press. Wilfried van de Ven graciously translated the abstract.

1 Margaret Angus, "Queen's College on William Street," Historic Kingston, XXXIV (1986), 86-98, gives the complex history of Browne's own house, 205 William Street, begun in 1841, but little physical evidence is left from Browne's era due to fire damage and alterations. Margaret Angus, "Architects and Builders of Early Kingston," Historic Kingston, XI (1963), 21-29, discusses Browne's work on the remodelling of Alwington House, illustrated in Marion MacRae and Anthony Adamson, Ancestral Roof (Toronto, 1963), 235. Browne's frame wing was removed by 1869 , and the remainder of the stone house burnt in 1958. It is, therefore, difficult to analyse this contribution to his domestic work. Angus notes in passing Browne's work on Hawthorne Cottage, "Architects and Builders," 27, and Old Stones of Kingston (Toronto, 1966), 83. MacRae gives Bellevue to Browne without substantially explaining her reasons, Ancestral Roof, 149. This is repeated in Leslie Mairland, et al., A Guide to Canadian Architectural Styles (Peterborough, 1992), 60.

2 For Browne's career see A.J.H. Richardson, et al., Quebec City: Architects, Artisans, and Builders (Ottawa, 1984), 117-19;and J. Douglas Stewart's entry in Dictionary of Canadian Biography, XI, 117-19.

3 Illustrated in France Gagnon-Pratte, L'architecture et la nature à Québec au dix-neuvième siècle: les villas (Québec, 1980), figs. 11922.

4 Coverdale's accounts specify payment for Rosemount's plans. The house survives, shorn of its verandahs. For further information on Coverdale, see the author's Ph.D. thesis, "William Coverdale and the Architecture of Kingston from 1835 to 1865," University of Toronto, 1991.

5 Roselawn is attributed to William Coverdale in Buildings of $A r-$ chitectural and Historic Significance, 6 vols. (Kingston, 1971-85) I, 97-99; J. Douglas Stewart and Ian Wilson, Heritage Kingston (Kingston, 1973), 194 (this passage gives the erroneous impression that Flynn's directory of 1857 states that Coverdale designed Roselawn); entry on Coverdale by Margaret Angus, Dictionary of Canadian Biography, IX, 165; and Mary Fraser, "William Coverdale, Kingston Architect, 1801?-1865," Historic Kingston, XXVI (1978), 71-80.

6 The drawing in Figure 2 is based upon customary stable arrangements, turn-of-the-century photographs (Kingston Psychiatric Hospital) and written descriptions of this building after its alteration of 1856-57 into an insane asylum for women. See the Daily British Whig, Kingston, 12 December 1857, 11 March 1868, and 21 January 1898.

7 Early photographs show that Rockwood's canopy had a similar fringe (now missing).
8 For a sensitive description of Rockwood Villa, see J. Douglas Stewart's chapter on Browne in Gerald Tulchinsky, ed., To Preserve \& Defend: Essays on Kingston in the Nineteenth Century (Montreal, 1976). For the building history of the Rockwood estate, see Jennifer McKendry, "An Ideal Hospital for the Insane?: Rockwood Lunatic Asylum, Kingston, Ontario," Bulletin of the Society for the Study of Architecture in Canada, XVIII (March 1993), 4-17.

9 Hawthorne Cottage disappeared when St. Mary's of the Lake Hospital was built on King Street West in 1910. I would like to thank the Sisters of Providence of St. Vincent de Paul for allowing me to photograph their painting of the cottage, dated 1908.

10 British Whig, Kingston, 11 August 1836. The architect is not identified.

11 Chronicle \& Gazette, 12 February 1841.

12 Chronicle of Gazette, 27 February 1841.

13 In a letter of 15 April 1841 Browne stated that he was waiting for H.H. Killaly's (in charge of public works) answer "about Mr. Murdock's house." Margaret Angus kindly shared her notes on this correspondence (collection of the National Archives of Canada, Ottawa, RG 11, PW1, vol. 38).

14 Otcawa, National Archives of Canada, RG 11, vol. 602, G. Browne accounts, no date, but likely from June of 1841 , because on 1 June Thomas Begley requested a financial statement from Browne of expenses of work completed for the Board of Works.

15 There are five clues for determining Browne's alterations and additions: first, Harper's sales notice (describing the cottage previous to Browne's involvement) for a square stone house of one storey with an attached garden house and basement service rooms; second, the written accounts by Browne for erecting a wing and awning; third, a newspaper notice (Kingston Daily News, 19 July 1867) that suggests the addition of a library, bathrooms, dressing rooms and a hot-air furnace since the 1841 sales notice; fourth, a detail in the 1869 map showing the cottage's ground plan as an L with a verandah; and fifth, the 1908 painting portraying a two-storey wing (with canopy and balcony) attached to the main part of the roughcast cottage of one storey, with a verandah on a base pierced by open arches and having a railing of geometric sunbursts between Tuscan columns. Rockwood has a Tuscan portico on the north and originally had a pair of Tuscan verandahs on the south (shown on a floor plan of 1857, Ottawa, National Archives of Canada, National Map Collection).

16 This date, accepted in such publications as Stewart and Wilson, Heritage Kingston, 151, is based upon a 1964 report by Margaret Angus for the Government of Canada. She argues that the inflaced price $(£ 1,217$ for nine-and-a-half acres) paid by Charles Hales in January 1841 must have included the house built three years earlier on land leased from owner Smith Bartlett (see note 18 for anorher view). National Historic Sites Services kindly allowed me access to this report that provided many helpful leads on newspaper sources. Janet Wright, Architecture of the Pictur- 
esque in Canada (Ottawa, 1984), 167, figs. 65-66, gives the date as after 1841, partially based on my findings for a graduate course in 1981 at Queen's University. A National Historic Site since 1967 because of its historical link with Sir John A. Macdonald, its fine architectural qualities have been recognized locally, nationally and internationally.

17 Wright mistakenly designates Bellevue as the first Italian villa built in Canada (Architecture of the Picturesque, 90) but this honour should be given to Robert Wetherell's 1834 Dundurn Castle in Hamilton. One might still honour Bellevue as the first moderately sized Italian villa with a tower in Canada; Dundurn Castle is much more ambitious in scale and ornament. Due to the ever-increasing publications encouraging the Italian style, variants on Bellevue's formula began to appear in greater numbers in the second half of the century.

18 Hales paid a substantial price for this land because he wished to subdivide it (not because it already contained Bellevue, as Angus has argued). Over the next few years he created five small lots for attached rental cottages along King Street West, a large lot for Bellevue with frontage along Centre Street, and twentyfive building lots on the remaining land on Centre and Union Streets. Although Kingston was not officially confirmed as capital until early February 1841, local gossip heralded this honour as early as autumn 1840: "The government keeps all things very quiet about purchases and don't [sic] like to raise too high notions in the owners but they cannot prevent it ...." Anne Macaulay to Helen Macaulay, Toronto, Archives of Ontario, Toronto, Macaulay Papers. Hales probably knew that his site was well located at the time of purchase: see Brian Osborne and Donald Swainson, Kingston Building on the Past (Westport, 1988), 80-81.

19 Four of Hales' cottages survive at 311-17 King Street West; for the tender, see Chronicle of Gazette, 9 May 1841. They were occupied by early 1843 when a tenant wished to dispose of his lcase (British Whig, 2 January 1843). Illustrated in Angus, Old Stones, 85.

20 Chronicle \& Gazette, 5 January 1842 and 13 January 1843. One can only speculate on other commissions Browne may have received from Hales, who was very busy as a land developer. In June $1841 \mathrm{Hales}$ advertised that he needed twelve masons and twelve carpenters for an unidentified project, and early in 1842 he was subdividing Block W, bounded by Barrie Street and Johnson Street. The Commercial Mart now sports a turn-ofthe-century mansard roof.

21 In the spring of 1844, at a time when he might well have been living in Bellevue, Hales advertised to lct one of his cottages and requested prospective tenants to contact him in Kingston (not nearby at Bellevue). This suggests that he was still living in his town house; British Whig, 23 April 1844. Bellevue was well outside the city boundaries until the 1850 annexation of Stuartsville.
22 Angus argues that an auction sale of household furniture mentioned in Kingston Herald, 30 April 1845, as "at the residence of Charles Hales, Esq." occurred at Bellevue House, but this is unlikely as Bellevue was considered to be outside of town (customary descriptions such as "on the Penitentiary Road" are missing).

23 Argus, 28 April 1846. The name "Bellevue Terrace" is first recorded in 1846 (Chronicle \& Gazette, 4 November 1846) and reappears on a map of 1865 . But two maps dated 1842 do not indicate a building on this site even though neighbouring houses appear (a military map in the National Map Collection, National Archives of Canada, Ottawa, and a map in Special Collections, Queen's University, Kingston - 613-9 edf 184-, maps of Kingston \& Wolfe Is.).

24 Hales went out of his way to mention that the building lots he had for sale were "part of the block where Mr. Browne, the architect, has erected his dwelling house." See Chronicle \& Gazette, 13 January 1842.

25 Queen's University Archives, Kingston, holds a number of books inscribed by Browne: William Halfpenny, A New and Compleat System of Architecture Delineated (London, 1749); James Gibbs, A Book of Architecture Containing Designs of Buildings and Ornaments, 2nd edn (London, 1739); Colin Campbell, Vitruvius Britannicus (vol. 4, 1767); and Asher Benjamin, The Architect or Complete Builder's Guide (Boston, 1845). I discuss the role of pattern books on local house design in my M.A. thesis, "Aspects of Domestic Architecture in South-eastern Ontario: Siting, Interiors, and Selected Furnishings of Frontenac, Lennox and Addington Counties, 1820-1850," Queen's University, 1984. A local bookseller offered to make arrangements with customers to have their overseas orders sent on "the Spring Vessels:" Chronicle \& Gazette, 27 December 1844. Books from the prolific pen of Benjamin, which did not involve the delays in publications from overseas, were particularly influential.

26 J.C. Loudon, Encyclopaedia of Cottage, Farm and Villa Architecture, new edn (London, 1839), 778-79.

27 Samuel Sloan, The Model Architect 2 vols (Philadelphia, 185152; repr. New York, 1980), I, 31.

28 Rockwood was explicitly described by Browne as an "Italian villa" in his tender call. See note 15 for the southern porticoes (now missing).

29 P.F. Robinson, Designs for Ornamental Villas, 4 th edn (London, 1836), 42. A copy of the third edition was owned by Kingston architect William Coverdale.

30 Macdonald to Margaret Greene, 15 August 1848, quoted in J.K. Johnson, ed., Affectionately Yours: The Letters of Sir John A. Macdonald and his Family (Toronto, 1969), 58.

31 Henry-Russell Hitchcock identifies John Notman's Doane house in Burlington, N.Y., of 1837 as the first towered Italian Villa in the United States. See his Architecture: Nineteenth and Twentieth Centuries 4th edn (Harmondsworth, 1978), 138. 